\title{
Pseudonovibos spiralis (Artiodactyla: Bovidae): new information on this enigmatic South-east Asian ox
}

\author{
Robert M. Timm ${ }^{1}$ and John H. Brandt ${ }^{2}$ \\ ${ }^{1}$ Natural History Museum \& Department of Ecology and Evolutionary Biology, University of Kansas, Lawrence, KS 66045, U.S.A. \\ ${ }^{2}$ Zoology Research Associate, Denver Museum of Natural History, P.O. Box 5003, Alamosa, CO, 81101, U.S.A. \\ (Accepted 21 January 2000)
}

\begin{abstract}
Two bovid frontlets with horns collected in 1929 and now housed in the collections of the University of Kansas Natural History Museum (KU) from Suoi Kiet, Binh Tuy Province, Vietnam, were previously identified as koupreys (Bos sauveli). We believe that they are specimens of the recently discovered bovid, Pseudonovibos spiralis Peter \& Feiler, 1994. The KU specimens are represented by the posterior half of the frontal bones, the parietals, the horn cores and horns, and the anteriormost supraoccipitals, and are the most complete, best documented, and oldest specimens known of this poorly known species. We believe that both an adult male and an adult female are represented. Although the specimens are fragmentary, they still provide significant information that allows us to describe some aspects of $P$. spiralis, and they are especially critical to our understanding of the relationships of this animal to other bovids. We propose the English name spiral-horned ox, which reflects both its distinctively shaped horns and close relationship to other wild oxen. The Khmer name, Khting Vor, is also an appropriate common name. Previously overlooked references from the 1880s and 1950s document that the spiral-horned ox was believed to have magical powers over poisonous snakes.
\end{abstract}

Key words: Bovidae, Indo-China, Pseudonovibos spiralis, South-east Asia, spiral-horned ox

\section{INTRODUCTION}

Much remains to be learned about Holocene mammals, as is amply demonstrated by the continuing discovery of new species and new genera. More than $16 \%$ of the currently recognized species (742 of 4629) have been described since 1930, and at least 17 of these are large mammals (Wilson \& Reeder, 1993; Pine, 1994). Four of these new large mammals have been the basis for descriptions of new genera. In South-east Asia, local hunters have long been familiar with several ungulates that had gone undetected by science until recently. The first of these 'newly discovered' ungulates, the saola or $\mathrm{Vu}$ Quang ox, Pseudoryx nghetinhensis (Artiodactyla: Bovidae), was found along the Vietnam-Laos border, and is currently known from more than 20 localities in the $\mathrm{Vu}$ Quang Nature Reserve in northern Vietnam and in adjacent Laos (Dung et al., 1993, 1994; Schaller \& Rabinowitz, 1995). The large-antlered or giant muntjac, Megamuntiacus vuquangensis (Artiodactyla: Cervidae), was also recently discovered in the Vu Quang Nature Reserve (Do Tuoc et al., 1994), and is now known from

*All correspondence to: Dr. Robert M. Timm.

E-mail: btimm@falcon.cc.ukans.edu a much wider area, particularly in Laos and along the Laos-Vietnam border (Schaller \& Vrba, 1996; Timmins et al., 1998; Duckworth et al., 1999). The common muntjac (Muntiacus muntjak) occurs commonly throughout the area, and recently a third muntjac has been reported (Schaller \& Vrba, 1996), which may be the species recently described as Muntiacus truongsonensis by Giao et al. (1998). Pseudonovibos spiralis (Artiodactyla: Bovidae) is the most poorly known of these new artiodactyls. It was described in 1994 on the basis of horns believed to be from six animals (Peter \& Feiler, $1994 a, b)$. To date, it is known only from detached horn sheaths or frontlets with horn sheaths from perhaps 16 animals.

Although $P$. spiralis was described on the basis of separate horns only, the horns are so distinct in appearance that there was little doubt that the animal was unknown to science and it was described as a new genus. The horns are annulated throughout their entire length and the tip is twisted, a combination not seen in any previously known mammal.

The Holocene mammal collection of the University of Kansas Natural History Museum (KU) contains two specimens of a Vietnamese bovid with these uniquely annulated horns with a twisted tip. These specimens 


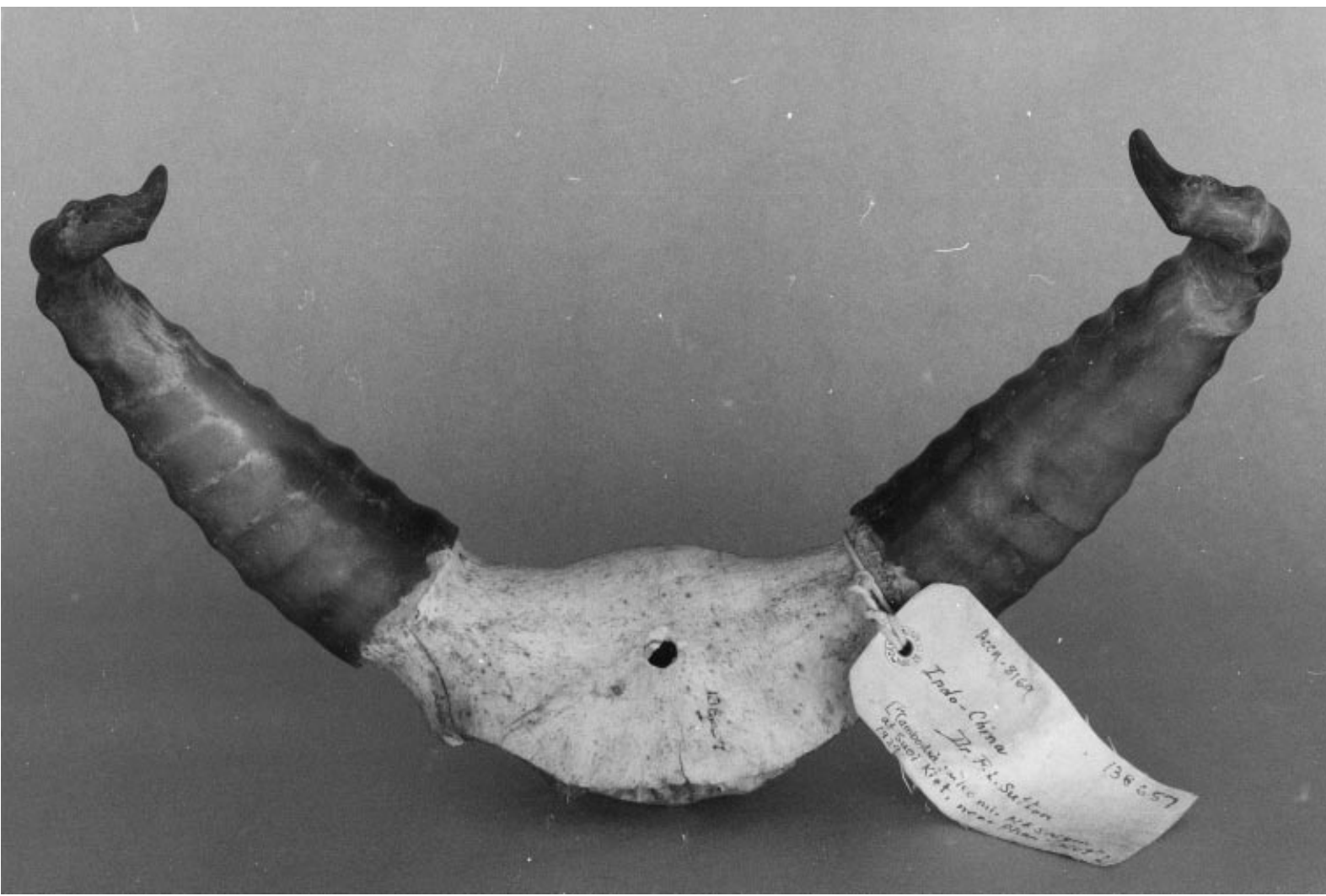

Fig. 1. Frontlet identified as of an adult spiral-horned ox (Pseudonovibos spiralis) (KU 138657), which we presume to be from a male. The least distance between the horncore tips is $305 \mathrm{~mm}$.

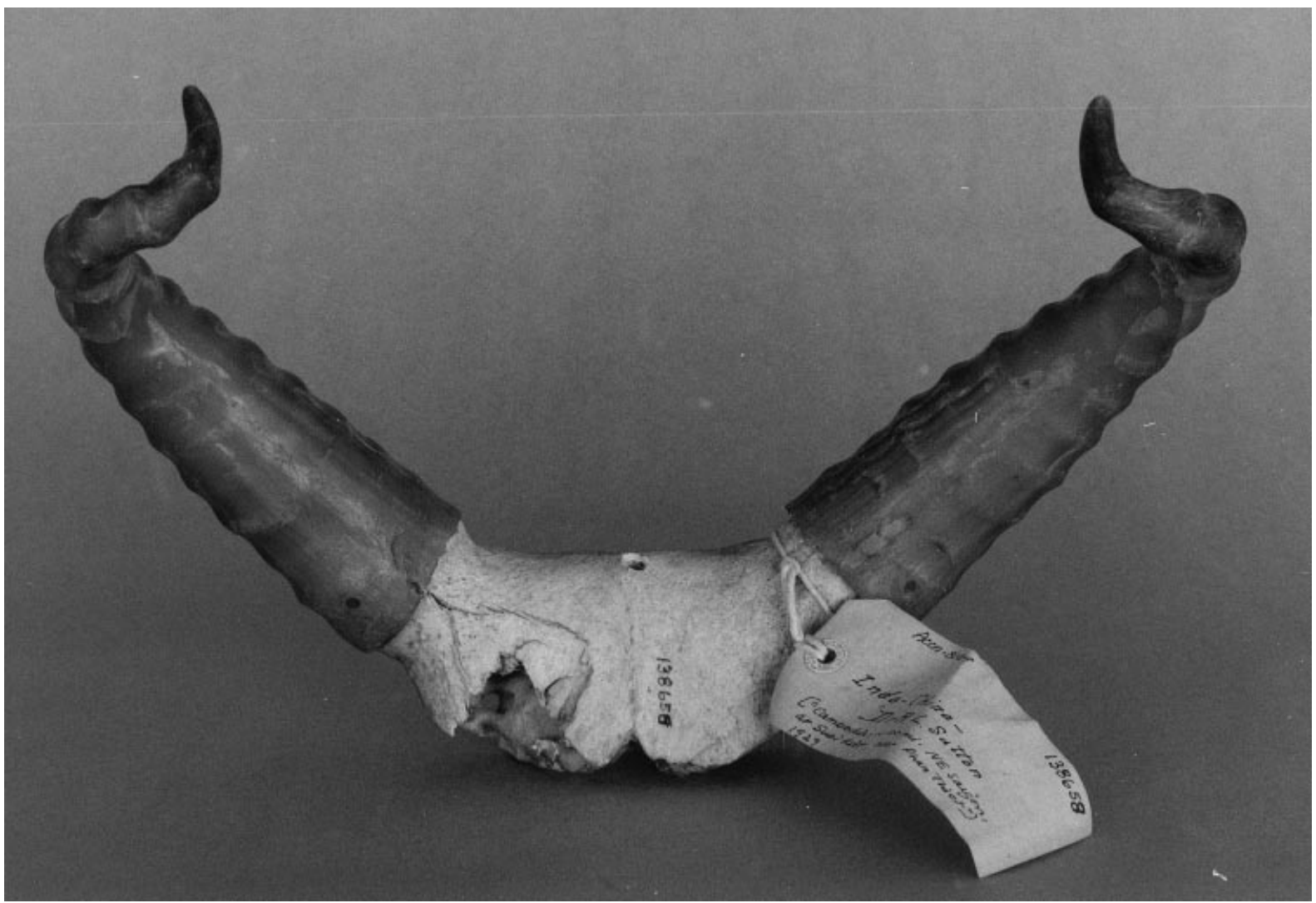

Fig. 2. Frontlet identified as of an adult spiral-horned ox (Pseudonovibos spiralis) (KU 138658), which we presume to be from a female. The least distance between the horncore tips is $275 \mathrm{~mm}$. 

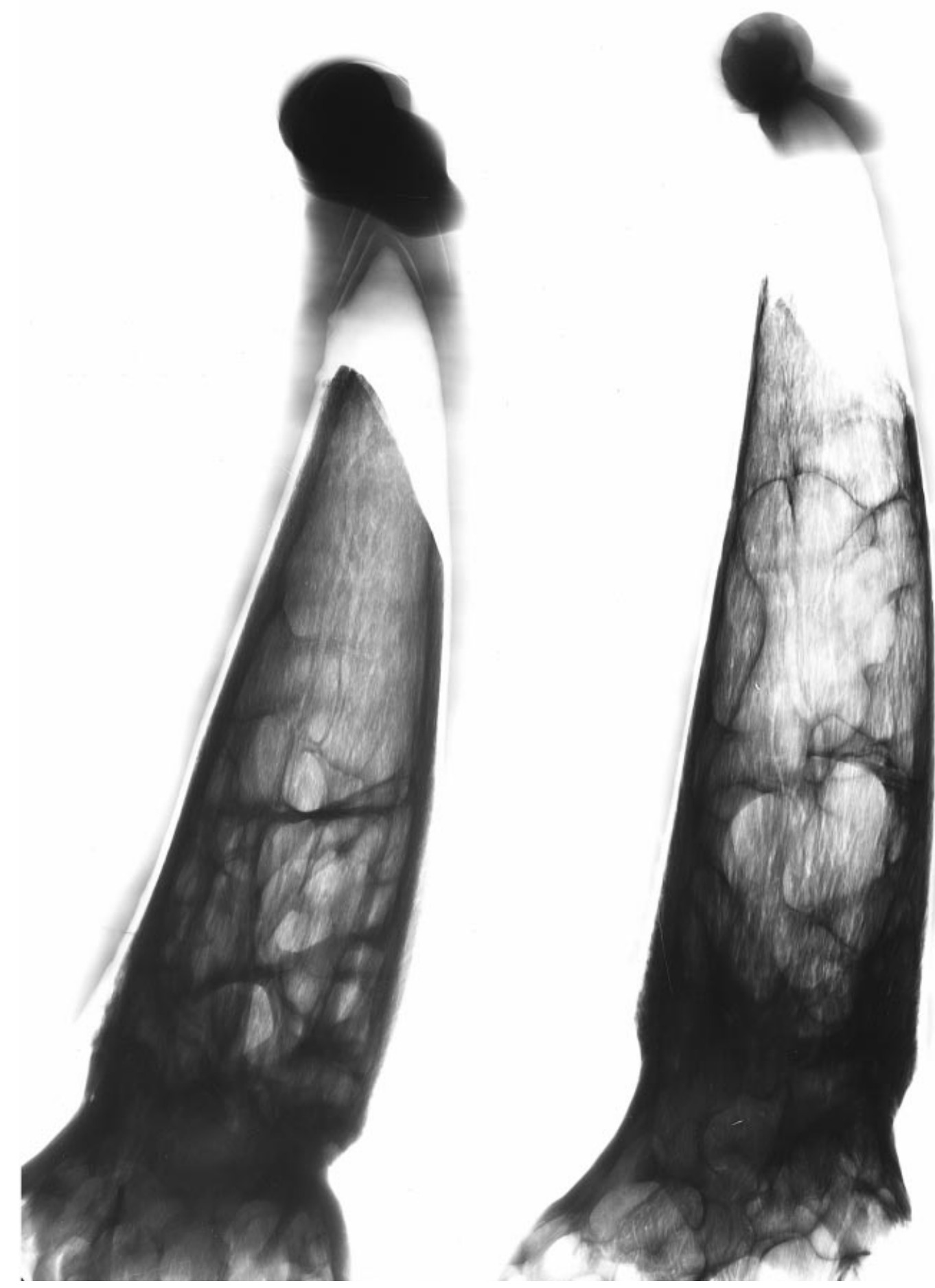

Fig. 3. Radiograph of the right horn sheaths and cores of two adult spiral-horned oxen (Pseudonovibos spiralis) (KU 138658 left; KU 138657 right). Note the characteristic bovid trabeculae that may be seen within the horn cores. The tip of the horn core has been sawn off on KU 138658 and the tip of KU 138657 has been broken off. This was done before the specimens were received at the University of Kansas in 1930. Given that these frontlets were in the Suttons' possession only months before they were donated to $\mathrm{KU}$, that the horn cores and sheaths are quite clean and all soft tissues have been removed, and that each horn is tacked to the bony core with a small nail, we suspect that the frontlets were boiled to remove the horns and the tips of the bony horn cores were sawn or broken off at that time to drain out the marrow as well as to remove the cartilaginous tip. This was a common practice of hunters in that era (and remains so today) to allow removal of the soft tissues from trophy heads to prevent noxious smells created by decomposition inside the horns and in the skull. However, because the numerous grooves of irregular bone deposition of the bony cores perfectly match the ridges in the horn sheaths, we are confident that the horns and frontlets are correctly matched sets and have not been switched with those of other animals. 
were reported previously as being immature female koupreys, Bos sauveli (Hoffmann, 1986). In their recent description of Pseudonovibos spiralis, Peter \& Feiler (1994b) stated, based upon the photograph and description provided by Hoffmann, that the specimens at the University of Kansas were conspecific with this newly described species. During 1994 and 1995 M. Dioli $(1995,1997)$ obtained an additional frontlet and isolated horn sheaths from wildlife markets in north-eastern Cambodia that are similar to those reported by Hoffmann, and he suggested that they too belonged to this new species of bovid.

Now that additional material and literature are available, our study of the specimens housed at the University of Kansas leads us to conclude that they are indeed $P$. spiralis, and represent the oldest, most complete, and best documented specimens known to date. The purposes of this paper are to confirm that two additional specimens of $P$. spiralis exist, to report that these specimens are represented by intact frontlets from wild-collected individuals that are accompanied by locality data, to provide new information on this poorly known animal, to review historical information on this species, and to suggest that it is most closely aligned with previously known Bovinae - the wild oxen, cattle, and buffalo.

\section{METHODS}

Specimens of bovids were examined in the collections of the Field Museum, Chicago; Museum of Vertebrate Zoology, University of California, Berkeley; University of Kansas Natural History Museum, Lawrence (KU); and the US National Museum of Natural History, Washington (USNM). The KU specimens were compared directly with those at the Field Museum and the US National Museum. The KU specimens also were compared with photographs, drawings, and measurements of many other taxa.

The measurements reported herein were taken to the nearest $\mathrm{mm}$ and include the width between the horns at their base, distance between the tips, and the angle of the horns. Width between the horns was taken as a straight line measure from the estimated centres of the bases of the bone horn cores where they attach to the frontal bones. The angle of the horns was taken as the angle at which the horns diverge laterally from the skull. The angle was measured using a carpenter's square with respect to a level placed perpendicular to the forehead (paired frontals) at the base of the horn. The angle at the inner edge of the horn was measured on both left and right horns for each animal. Horn colour follows Ridgway (1912).

In an attempt to ascertain the relationship of these problematic frontlets to other artiodactyls, we examined characters used in recent phylogenetic studies on various artiodactyls (Groves, 1981; Janis \& Scott, 1987; Geraads, 1992; Thomas, 1994).

\section{RESULTS}

Two specimens of bovid frontlets in the KU collections (KU 138657 \& 138658), with locality data reading 'Vietnam: Suoi Kiet, about $125 \mathrm{~km} \mathrm{NE}$ of Ho-chi-minh City' (Binh Tuy Province) are herein assigned to the newly described P. spiralis Peter \& Feiler, 1994 (Artiodactyla: Bovidae). The locality data on the specimen tags was reconstructed in 1946 by E. R. Hall and Richard L. Sutton, Jr., and was reconfirmed in 1985 by Sutton and R. S. Hoffmann. The animals were collected in January 1929 by Richard L. Sutton, Jr., who along with his father, Dr Richard L. Sutton, was hunting in what was then French Indo-China (Sutton \& Sutton, 1930). The specimens are represented by skull frontlets consisting primarily of the posterior half of the frontal bones, the parietals, horn cores and horns, and the anteriormost supraoccipitals (Figs 1, 2 \& 3). Photographs of an adult male and 2 female kouprey (Bos sauveli) skulls are provided for comparison (Figs 4,5 \& 6).

The horns are distinctive and are postorbital, unbranched, spiralled, twisted, covered by a keratin sheath, and nondeciduous. The remarkable features of the keratinized horn sheaths are that they have a distinct lyriform twist as well as annulations for their entire length. The $\mathrm{C}$-shaped annulations are not uniformly high rings around the horn for its entire length - for the basal two-thirds of the horn length, the annulations are nearly flat anterodorsally. The horn cores are typical, well-ossified bovid bony horn cores that extend upward and outward from the posterior lateral frontals. One animal (KU 138657) has oval horn cores in cross section, those of the other (KU 138658) are more circular in cross section. KU 138657 has 12 annulations on the right horn and 13 on the left; KU 138658 has 13 annulations on both the right and left horns. The distance between the horn cores and tips is greater in KU 138657 (width at horn core base $=132 \mathrm{~mm}$; tip distance $=305 \mathrm{~mm}$ ) than in 138658 (width at horn core base $=103 \mathrm{~mm}$; tip distance $=275 \mathrm{~mm}$ ), and the horns come off the skull at a slightly more oblique angle (c. $45^{\circ}$ vs. $43^{\circ}$ ). The curvature of the horns as seen in side view is slightly concave. The general horn colour is dull ochre brown and most closely matches buckthorn brown or Dresden brown of Ridgway (1912; plate XV). The horns are smooth and have considerable sheen, an opalescent shine, more so than any of the Ridgway colours. The forehead of both animals is relatively flat, and an intercornual ridge is present. On KU 138657 the intercornual ridge is slight, but present; on KU 138658 a distinct medial, low, rounded ridge runs from the anterior edge of the supraoccipital across all of the frontals that remain. KU 138657 has a broader, flatter forehead than does the other specimen. Both animals were clearly mature adults as evidenced by complete fusion of the cranial sutures.

Distinguishing characters of these frontlets are horn cores of medium length, horn cores inserted behind orbits, horn cores inserted widely apart, horn cores very 


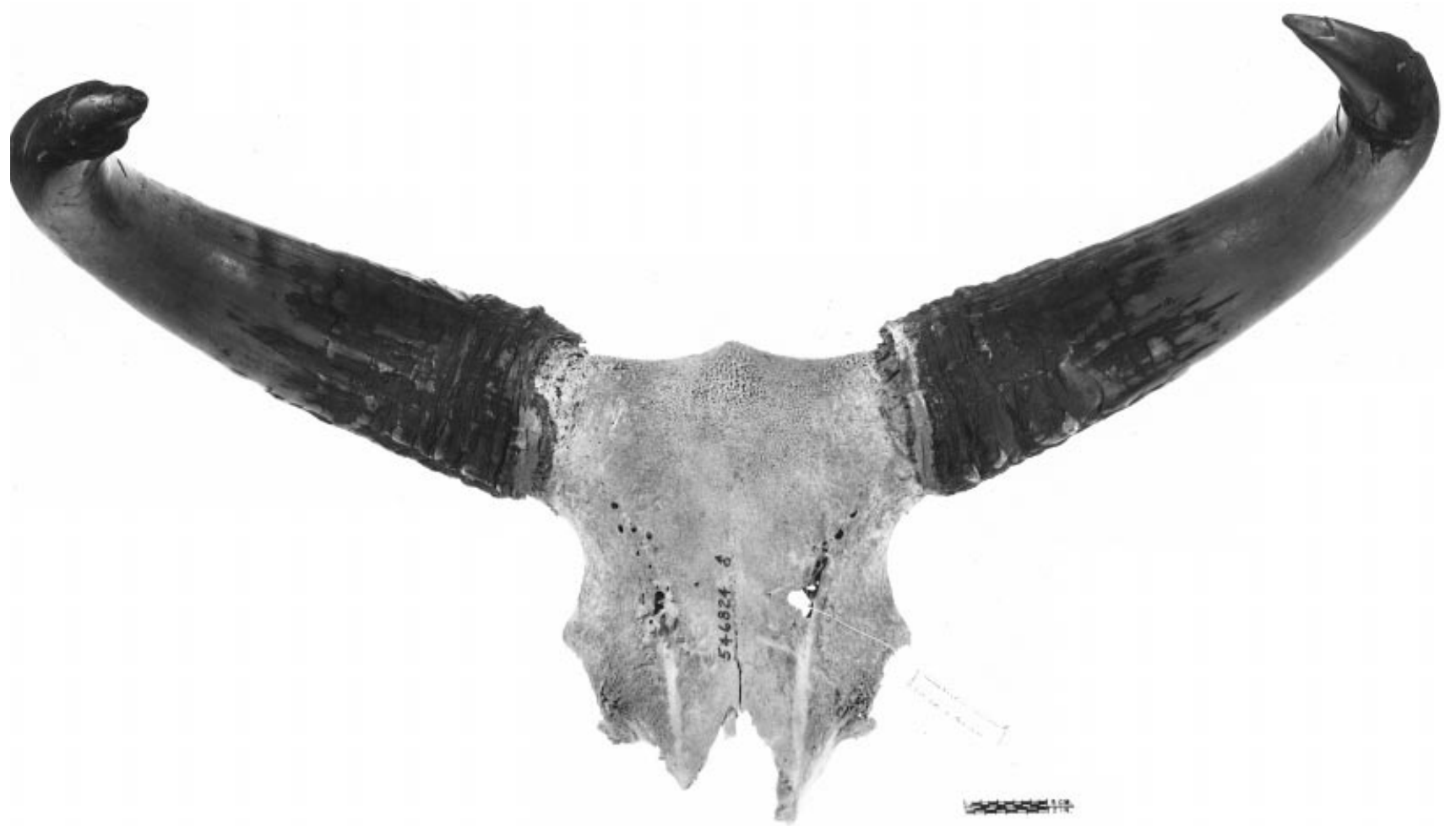

Fig. 4. Skull and horns of an adult male kouprey (Bos sauveli) to show the characteristic massive horns that sweep outwards at an obtuse angle and are frayed at the tip. Several skulls of old males display more fraying at the horn tips (USNM 546824). Scale bar $=5 \mathrm{~cm}$.
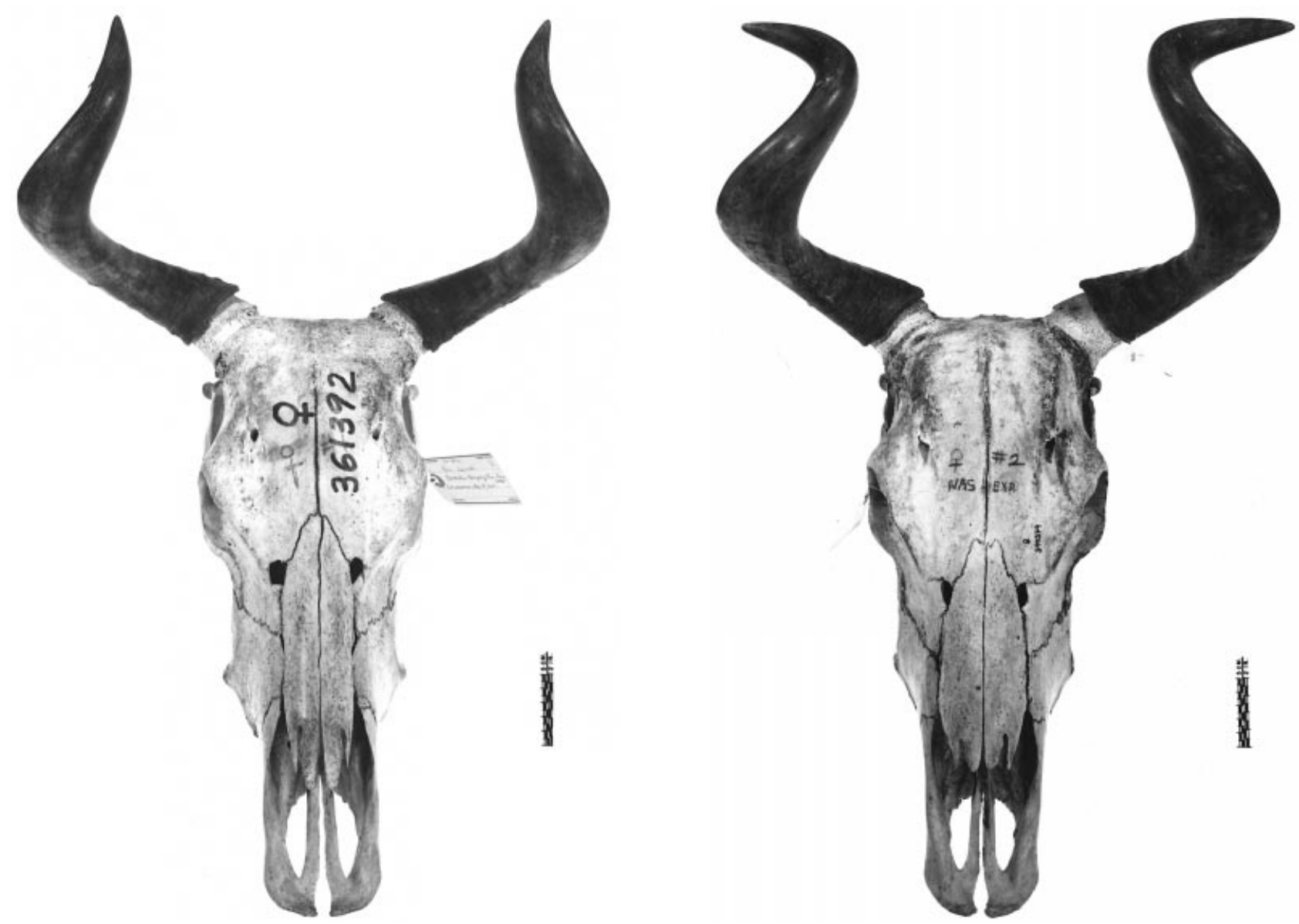

Figs 5 \& 6. Skull and horns of two adult female koupreys (Bos sauveli) to show the upward spiral of the horns. Note that the horns are not annulated (USNM 361392 right; USNM 399379 left). Scale bars $=5 \mathrm{~cm}$. 
divergent from one another, horn cores inclined posteriorly in side view in relation to frontals, horn cores with extensive internal trabeculae or sinuses, temporal crest behind horn core weak, surface between horn cores smooth (not roughened), and frontals with extensive internal sinuses (Figs 1, 2 \& 3). This suite of characters places Pseudonovibos in the bovid subfamily Bovinae.

\section{DISCUSSION}

Because the KU horns quite closely match the description of $P$. spiralis by Peter \& Feiler (1994b), there is no reason to doubt that they represent the same species - a conclusion also reached by Peter \& Feiler. This match is especially clear when comparing the KU specimens to the photograph of the holotype in Peter \& Feiler (1994b: 171, figs $5 \&$ 6). Size, extent of the twist at the tip, and colour differ, but these are likely to be geographic, individual, or age variation (or post-mortem change) and not species-level differences. We are now able to state that figs 5 \& 6 of Peter \& Feiler (1994b: 171) represent the left and right horns, respectively, viewed posteriorly.

Hoffmann (1986: 393) provided a summary of how and where the KU frontlets were collected, and how they came to be deposited at KU. He described the locality as follows: 'I cannot find Suoi Kiet on modern maps, but it is shown on a map ... in Coolidge and Roosevelt (1933), although spelled Soui Kiet; it is about $125 \mathrm{~km} \mathrm{NE}$ of Ho-chi-min City (formerly Saigon), and $70 \mathrm{~km}$ NW of Phan Thiet'. As Hoffmann detailed, the specimens were donated to the University of Kansas by the collectors, Dr Richard L. Sutton and his son, Dr Richard L. Sutton, Jr., in 1930. However, because the specimens were not accompanied by locality data or an identification at that time, they were not catalogued into the main collection. In 1946, E. Raymond Hall, the Director of the KU Museum of Natural History, met with Richard L. Sutton, Jr., and they were able to reconstruct the locality data (Hall's field notes dated 28-29 July 1946). In 1985, Richard Sutton, Jr. reconfirmed the locality and collection data with Robert S. Hoffmann, and reported to him that the animals were shot for meat or tiger bait and were not considered trophies at the time (Hoffmann, 1986). Other species of mammals the Suttons collected at this locality, which we interpret as belonging to the same mammal community, include three species of deer (hog deer Axis porcinus annamiticus, brow-antlered deer Cervus eldii siamensis, and sambar Cervus unicolor equinus), as well as gaur (Bos gaurus readei), banteng (Bos javanicus birmanicus), tiger (Panthera tigris corbetti), and Malayan sun bear (Ursus malayanus) (Sutton \& Sutton, 1930; artiodactyls confirmed by specimens in the KU collections). This locality is referred to as the 'Suoi Kiet Railway Camp', which was on the railroad about 35 miles west of Suoi Van (Sutton \& Sutton, 1930: 283).

Peter \& Feiler $(1994 a, b)$ reported that $P$. spiralis occurs in the highlands of Da Lat and was known from
Buon Ma Thuot (= Ban Me Thuat), Dac Lac (= Darlac), and Cong Tum (= Kontum or Contum) in Vietnam and the north-east districts of Rattanakiri and Mondulkiri in adjacent Cambodia. All their specimens were purchased from traders in markets. The KU specimens from Suoi Kiet are from considerably south of the previous records, which suggests that $P$. spiralis was at one time more widely distributed.

Most bovids are sexually dimorphic, with adult males being larger and having larger and longer horns than females. We interpret the differences in size and forehead shape observed in our two specimens as sexual dimorphism, with the larger frontlet having the broader, flatter forehead, and the horns diverging out at a slightly more oblique angle as being of a male (KU 138657), and the smaller frontlet with the more distinctive intercornual ridge as being a female (KU 138658). If this interpretation is correct, sexual dimorphism also includes the shape of the horns and horn cores; the broad, oval horns in cross section are from the male and the more circular horns are from the female. Peter \& Feiler (1994b) also regarded the two horn core shapes of their series (round vs. more elliptical) as representing sexual differences, but do not speculate which shape is associated with males and which with females. Pseudonovibos is of interest in the relatively minor degree of sexual dimorphism apparently present.

The annulations on both specimens from Suoi Kiet are C-shaped and well pronounced posteriorly, whereas they are reduced to being nearly non-existent on the anterior surface of the horn sheaths. This pattern is true for both the left and right horns on each animal. Peter \& Feiler (1994b) also noted the flattened surface of the annulations, but also stated that some of their specimens had annulations completely surrounding the horn (pers. comm.).

The horn colour of both KU specimens from Suoi Kiet might best be described as a dull ochre brown. We suspect that the specimens from Suoi Kiet are close to the original horn colour despite nearly seven decades of storage. Horn colour was described as blackish by Peter \& Feiler (1994b), and all their photographs clearly show very dark horns. M. Dioli has informed us that almost all the horns recently discovered are old, and that most of these have been smoked. Some local hunters believe that Pseudonovibos feed on poisonous snakes and that the snake poison then impregnates the horns. Hunters smoke the horns as soon as possible after an animal is shot because smoking is believed necessary to protect whoever touches the horns against this poison.

Although the material available to us is fragmentary, we are fortunate in that several characters used by previous authors to assess relationships of artiodactyls are present. Pseudonovibos spiralis is clearly a member of the family Bovidae because it shares with all other known bovids the unique horn characteristics of unbranched nondeciduous bone cores with an unbranched nondeciduous keratin sheath.

The relationship of $P$. spiralis to other bovids has been the subject of considerable interest in the limited 
scientific literature that is available (Feiler \& Nadler, 1997; Hammer et al., 1999; Nowak, 1999), in the popular press (Schaller, 1998; 1999), and in the common names used for this animal. The Vietnamese name, Linh Duong, reported by Peter \& Feiler $(1994 a, b)$ for this species was translated as 'mountain goat' or 'jungle sheep'. However, this is an inappropriate common name to use for $P$. spiralis because it is actually a rural Vietnamese name for the serow, Nemorhaedus sumatraensis (Bovidae: Caprinae). The only goat- or sheeplike mammal of South-east Asia occurring in Vietnam and adjacent Cambodia is the serow (Lekagul \& McNeeley, 1977). The serow has short, thick, black, weakly annulated horns that, although slightly similar to those of $P$. spiralis, can be easily distinguished from them. Hoffmann (1986) identified the specimens described herein from Suoi Kiet as kouprey, Bos sauveli (Bovidae: Bovinae). Peter \& Feiler (1994a) suggested that $P$. spiralis was most closely related to the Mongolian gazelle, Procapra gutturosa (Bovidae: Antilopinae), or perhaps the saiga, Saiga tatarica (Bovidae: Antilopinae), because these eastern Asian bovids have similarly ringed horns. Hammer et al. (1999) and Nowak (1999) suggested that Pseudonovibos was most closely related to the goats of the subfamily Caprinae. However, the mitochondrial cytochrome $b$ sequences analysed by Hammer et al. (1999) and compared to other bovids, were not from the holotype specimen and it seems probable that the type series is a composite of horns of more than one species of bovid. W. Duckworth (pers. comm.) informed us that the name Linh Duong is not associated with Pseudonovibos by the Vietnamese in any specific way. The Khmer name for this animal, Khting Vor (or Kating or Kting Voar), has been translated as 'wild cow that has horns like vines' (Dioli, 1997: 530). Dioli translated another Cambodian name, Kating Sipuoh (= Sipu), as 'wild cattle that eats snakes'. Desai \& Lic (1996) translate Khting Vor as Khting = gaur and $V o r=$ spiral climber or liana, which they believe is a description of the animal's deeply ridged, spiral horns. A more literal translation of Khting Vor would be 'vine cow' or 'twist cow' (W. Duckworth \& V. Lic, pers. comm.).

Although the horn annulations in the specimens of $P$. spiralis from Suoi Kiet are reminiscent of those in both Mongolian gazelles and saiga, there is little similarity in the horn placement on the skull and angle of the horns. Mongolian gazelles, as well as all other species of gazelles, and saiga have horns that originate quite close together, and in these species the elongate, annulated horns extend back posteriorly over the top of the skull, extending above the neck, and then diverge at a relatively acute angle from their close origin. However, in the KU frontlets, identified by us as P. spiralis, the horns diverge from the posterolateral margin of the skull at an oblique angle, and the distance between the bases of the horn cores is considerably greater than in Procapra. In Mongolian gazelles the annulations are small and numerous, whereas in both $P$. spiralis and saiga the annulations are larger and few in number.
Of the nine subfamilies of bovids currently recognized in the family Bovidae (Aepycerotinae, Alcelaphinae, Antilopinae, Bovinae, Caprinae, Cephalophinae, Hippotraginae, Peleinae, and Reduncinae [Grubb, 1993]), we believe that $P$. spiralis shares the greatest number of characters with the Bovinae, which includes the bison (Bison), oxen (Bos), Asian water buffalo, tamaraw, and anoas (Bubalus), and African buffalo (Syncerus). Pseudonovibos is not a goat or sheep (in the English or taxonomic sense of the words) or gazelle, but rather a wild ox or buffalo. Because we lack adequate material for a phylogenetic analysis at this time, we are unable to resolve the relationship of $P$. spiralis to other members of the Bovinae. The species is likely to be part of a clade that includes the wild oxen, and thus is closely related to the kouprey. We propose the English name of spiralhorned ox, which reflects both the distinctively shaped horns and specific name. The local Cambodian Khmer name, Khting Vor, is also appropriate as a common name for $P$. spiralis because it is the one common name available that we can unambiguously associate with this ox and if any animals remain extant, they are most likely to be found in Cambodia (W. Duckworth, pers. comm.).

Although no data or descriptions of the overall size of the spiral-horned ox are available, a comparison can be made with the kouprey based upon the frontlets that are available. The distance between the inner edges of the horn core bases of the large and the small spiral-horned ox are $80 \%$ of the same measurements taken on a male and a female kouprey, respectively. W. Duckworth informs us that Khmer villagers familiar with Khting Vor say it is smaller than wild cattle, being not much bigger than a sambar, although much more stocky.

The kouprey and Pseudonovibos may have been confused with one another by foreign hunters and scientists since 1930. Francois Josef Defosse, a professional hunter and guide in South-east Asia, and his son, Louis Hughes Augustus Defosse, served as the Suttons' guides in Indo-China. Francois Defosse was an extremely experienced hunter. The Suttons described him as having 'killed, or helped others to kill, more tigers than any other single individual in the world', which was in part why he was selected as their guide (Sutton \& Sutton, 1930: 235). In early January 1929, Richard Sutton, Jr. (who was on his first hunting expedition in South-east Asia) and Louis Defosse (who was 18 at the time and an accomplished hunter) travelled together to the Suoi Kiet Railway Camp, which the Suttons described as being fully 100 miles from their previous camp, where the fathers continued hunting. Both groups were hunting primarily for Asiatic elephants (Elephas maximus) and tigers. The two KU specimens of $P$. spiralis came from this Suoi Kiet Camp, but apparently neither the younger Sutton nor the younger Defosse realized that the odd, spiral-horned bovid that they collected was anything unusual. The Suttons (1930) made no mention of the specimens in their book, The Long Trek, in which they included numerous excellent photographs of trophy animals, people, and cultural 
sites. These bovids apparently were considered just meat for the camp or tiger bait, rather than trophies. As an experienced professional hunting guide, it seems likely that Francois Defosse would have recognized this animal as something different had he seen it in the flesh. Coolidge (1940: 515) wrote, 'In August, 1929 ... I joined Theodore Roosevelt in Saigon. He had just completed a rainy-season hunt with Defosse and his son Louis, during which he procured skins and skeletons of gaur and bantin as well as various deer ... I distinctly remember Defosse mentioning in conversation an interesting little-known wild ox that he had heard of. The logical suggestion was made that it might be a bantingaur hybrid or some strain of native cattle that had gone wild. The following year Defosse (1930) sent me his privately printed circular to interest hunting parties in which he definitely refers to the kouprey'. Urbain (1937) and Coolidge (1940) both cited this circular as the first published record of the kouprey's existence. However, as both Francois and Louis Defosse continued to lead hunting parties to the Suoi Kiet region, it is possible that they associated the odd, spiral-horned animal that Louis and Richard Sutton, Jr., collected with the name kouprey when they learned of the kouprey's existence. Thus, the 'kouprey' referred to in their hunting circular actually may have been $P$. spiralis. It is also possible that additional specimens of $P$. spiralis exist that were taken by other game hunters led by the Defosses to this region.

The earliest reference we are aware of providing evidence for the existence of both the spiral-horned ox and kouprey is M. Edgar Boulangier's Un hiver au Cambodge; chasses au tigre, a l'éléphant et au buffle sauvage. Boulangier, a French civil engineer, sailed from France to Vietnam in July 1881 and spent more than 6 months travelling in Cambodia and recording his observations on the country. One of his interests was big game hunting, and as a footnote to a section on hunting, he described Cambodia's wild bovids as (Boulangier, 1888: 206-207; our translation):

The Cambodian people recognise five species of wild ox: the kou-preii, the khting, the khting-tia, the khting-pôs, and the ansong. The khting-pôs is also called the snake khting by the indigenous people, who believe the animal feeds upon snakes, which it pierces with its sharp horns or seizes by the tail when the reptiles seek refuge down holes. The bites do not bother the khting in the slightest, say the indigenous people: at the most, several hairs are poisoned. Ejecting its saliva upon snakes, the ox makes them fall from the trees; it would have the same power against men. The horns of the beast, carried as a talisman, are used to guard against snakebite.

Boulangier's kou-preii is probably the kouprey, and if so, predates Defosse's reference to this species by more than three decades. Khting is the Cambodian name for gaur and ansong is the name for banteng (Wharton, 1957). We believe Khting-pôs is P. spiralis, because both Wharton (1957) and modern-day Khmer hunters associate the spiral-horned ox with having magical powers over the numerous poisonous snakes of the region and its horns as providing protection against snakes and a cure for snakebite. We are uncertain what animal khting-tia refers to. The only other ox-like bovid of the region that we know of is the water buffalo (Bubalus bubalis), which Boulangier calls buffle.

Wharton (1957: 7) in his monograph on koupreys, had reports of other 'contemporary oxen which resemble the kouprey', but he was unable to document these animals. He reported (pp. 7-8) 'The word kou-proh has been applied by the Cambodians to a legendary wild ox which is reputed to eat snakes and to dig in termite mounds after them. It is reported to be a smaller animal than the kouprey and is often blotched. It is said that if its horns are placed about the house no snakes will enter it, or if a horn is placed in a snake hole, the inmate will die within its lair. For the treatment of snake-bite, it is said that powdered kouproh horn is drunk and applied directly to the wound . . . Usage of the word "kouproh" to designate also a group of strangely blotched wild cattle living in an area east of the Mekong was found'. The observation of a bovid digging and feeding in termite mounds might have originated with animals seen feeding upon the soil brought up to the surface by the mound-building termites. This soil can be an important source of minerals in regions where rainfall is heavy. Wharton (1957: 9) stated that the suffixes prey and proh both mean forest in the respective dialects involved.

Considerable confusion exists in the meagre literature on $P$. spiralis as to the identity of many of the specimens reported and illustrated, as well as its relationship to other artiodactyls. In studying the photographs of horns published by Peter \& Feiler (1994a,b), Dioli (1995, 1997), and Macdonald \& Yang (1997), and the two KU specimens of $P$. spiralis, we believe that perhaps not all animals that have previously been assigned to $P$. spiralis represent that species. However, the horns that were selected as the holotype of $P$. spiralis clearly seem to be conspecific with the specimens housed at the University of Kansas, and we are happy to assign them to that species. Macdonald \& Yang (1997) suggested that an illustration of a Chinese artiodactyl published in 1607 could be attributed to Pseudonovibos. However, the animal appears to be a gazelle- or goatlike bovid based on the apparent close proximity of the horns at their bases where they attach to the frontals. The horns described and illustrated by Nadler (1997: fig. 2) and attributed to $P$. spiralis are mounted on a carved head, resembling that of a goat-like artiodactyl. The close positioning of the horns at their bases clearly indicates that either their placement is erroneous or that they were from another species. We believe that the archaeological material that Hoffmann (1986) reported from Yunnan, China, as kouprey does depict that species. The two horn sheaths obtained at Mondolkiri in eastern Cambodia by Desai \& Lic (1996: plate 1a) are correctly identified as $P$. spiralis and we believe represent two different individuals. Illustrations, photographs, and descriptions of all known Eurasian Bovinae are provided by Brandt (1996). 
The frontlets of $P$. spiralis described here share the greatest number of characters with the Bovini, the Bison-Bos-Bubalus-Syncerus clade, which Gentry (1992: 15) characterized as having 'low and wide skulls, horn cores in both sexes emerging transversely from the skull, internal sinuses in the frontals and horn cores . . . T They lack strong temporal ridges.

Pine (1994) pointed out that the number of new species of mammals described per decade has increased since the 1930s, with at least 50 new species of mammals described to date. A new muntjac, Muntiacus truongsonensis, was recently named from the Annamite mountains of Indo-China by Giao et al. (1998). The enigmatic species Muntiacus rooseveltorum has been rediscovered after a gap of decades (Amato et al., 1999a), and another new species, Muntiacus putaoensis, has been described from Burma (Amato et al., 1999b). Muntiacus putaoensis is distinctive, but a considerable amount of confusion exists concerning the Annamite species. Although treated by Amato et al. (1999a: 639) as $M$. rooseveltorum, the small, dark muntjac referred to in Schaller \& Vrba (1996) and portrayed in various popular sources (e.g. Timmins, 1996) is highly likely to correspond to M. truongsonensis (W. Duckworth, pers. comm.). Ongoing examination of various muntjac specimens from Laos and Vietnam indicates that considerable work is needed before the number of taxa and their distinguishing features become clear. The recent description of two new species of muntjac, Pseudoryx, and Pseudonovibos and the confusion in the literature concerning the identities of these and other South-east Asian artiodactyls highlights how little is known about mammals in the region.

Throughout Indo-China, the large mammals of open lowland deciduous forests have been subjected to overhunting, habitat destruction, and encroaching human populations as this habitat type has been increasingly used by humans in recent decades. Additionally, the political instability and wars that have afflicted the region have had a devastating impact upon wildlife. If Pseudonovibos was an animal of open lowland deciduous forests, it must be assumed that if it is not already extinct, the few populations that remain are small, effectively isolated, and subject to both considerable hunting pressure and the effects of habitat destruction. Populations of a number of vertebrates in this habitat type, including banteng, hog deer, and brow-antlered deer, have collapsed throughout the region (Desai \& Lic, 1996). Pseudonovibos spiralis is listed as Endangered by the IUCN (IUCN, 1999). The new discoveries in Indo-China, especially those of large mammals, are exciting, but the rapid destruction of natural habitats demands that expanded conservation efforts be undertaken to document and conserve these and other species.

\section{Acknowledgements}

We thank Michael D. Carleton, Linda K. Gordon, and Robert D. Fisher (USNM), Barbara R. Stein and James
L. Patton (University of California, Berkeley), and Lawrence R. Heaney and Bruce D. Patterson (Field Museum, Chicago) for allowing us to examine specimens under their care at their respective institutions. Barbara L. Clauson photographed the specimens used as Figs $1 \& 2$ and provided valuable comments on earlier drafts of this manuscript. William Duckworth and Ronald $\mathrm{H}$. Pine provided significant insights into South-east Asian mammals and critical reviews of the manuscript. Maurizio Dioli, Jan Saysette, and David Watson freely shared their knowledge and expertise with us, which improved the manuscript. Mike Greer and George B. Rabb of Brookfield Zoo provided the kouprey photographs used as Figs 4, 5 \& 6. John Chorn's expertise in producing the radiograph used as Fig. 3 is gratefully appreciated.

\section{REFERENCES}

Amato, G., Egan, M. G., Schaller, G. B., Baker, R. H., Rosenbaum, H. C., Robichaud, W. G. \& DeSalle, R. (1999a). Rediscovery of Roosevelt's barking deer (Muntiacus rooseveltorum). J. Mammal. 80: 639-643.

Amato, G., Egan, M. G. \& Rabinowitz, A. (1999b). A new species of muntjac, Muntiacus putaoensis (Artiodactyla: Cervidae) from northern Myanmar. Anim. Conserv. 2: 1-7.

Boulangier, M. E. (1888). Un hiver au Cambodge; chasses au tigre a l'éléphant et au buffle sauvage. 2ième edn. Tours, France: Alfred Marie et fils.

Brandt, J. H. (1996). Horned giants: Hunting Eur-Asian wild cattle. Huntington Beach, California: Woodbine (Safari Press) Publishing Co.

Coolidge, H. J., Jr. (1940). The Indo-Chinese forest ox or kouprey. Mem. Mus. Comp. Zoöl., Harvard, 44: 421-531+ 11 pls.

Coolidge, H. J. \& Roosevelt, T. (1933). Three kingdoms of IndoChina. New York: Thomas Y. Crowell Company.

Desai, A. \& Lic, V. (1996). Status and distribution of large mammals in eastern Cambodia: results of the first foot surveys in Mondulkiri and Rattanakiri provinces. Fauna \& Flora International, World Wide Fund for Nature, and IUCNThe World Conservation Union. Bangkok: DYNA Print Ltd.

Dioli, M. (1995). A clarification about the morphology of the horns of the female kouprey. A new unknown bovid species from Cambodia. Mammalia 59: 663-667.

Dioli, M. (1997). Notes on the morphology of the horns of a new artiodactyl mammal from Cambodia: Pseudonovibos spiralis. J. Zool. (Lond.) 241: 527-531.

Do Tuoc, Vu Van Dung, Dawson, S., Arctander, P. \& MacKinnon, J. (1994). [Introduction of a new large mammal species in Vietnam]. Hanoi: Forest Inventory and Planning Institute (Science and Technology News, 4-13 March). (In Vietnamese.)

Duckworth, J. W., Timmins, R. J., Khounboline, K., Salter, R. E. \& Davidson, P. (1999). Large mammals. In Wildlife in Lao PDR: 1999 Status Report. Duckworth, J. W., Salter, R. E. \& Khounboline, K. (Compilers). Gland, Switzerland: Vientiane: IUCNThe World Conservation Union/Wildlife Conservation Society/Centre for Protected Areas and Watershed Management.

Dung, V. V., Giao, P. M., Chinh, N. N., Do Tuoc, Arctander, P. \& MacKinnon, J. (1993). A new species of living bovid from Vietnam. Nature (Lond.) 363: 443-445.

Dung, V. V., Giao, P. M., Chinh, N. N., Do Tuoc \& MacKinnon, J. (1994). Discovery and conservation of the Vu Quang ox in Vietnam. Oryx 28: 16-21. 
Feiler, A. \& Nader, T. (1997). Recently discovered mammals in Vietnam: Present results on taxonomy, zoogeography, status and on the protection of the animals (Mammalia). Zool. Abh. Dresden 49: 331-335.

Gentry, A. W. (1992). The subfamilies and tribes of the family Bovidae. Mammal Rev. 22: 1-32.

Geraads, D. (1992). Phylogenetic analysis of the tribe Bovini (Mammalia: Artiodactyla). Zool. J. Linn. Soc. 104: 193-207.

Giao, P. M., Tuoc, D., Dung, V. V., Wikramanayake, E. D., Amato, G., Arctander, P. \& MacKinnon, J. R. (1998). Description of Muntiacus truongsonensis, a new species of muntjac (Artiodactyla: Muntiacidae) from Central Vietnam, and implications for conservation. Anim. Conserv. 1: 61-68.

Groves, C. P. (1981). Systematic relationships in the Bovini (Artiodactyla, Bovidae). Z. Zool. Syst. Evol. 19: 264-278.

Grubb, P. (1993). Order Artiodactyla. In Mammal species of the world: A taxonomic and geographic reference: $377-414$. Wilson, D. E \& Reeder, D. M. (Eds). 2nd edn. Washington, D.C.: Smithsonian Institution Press.

Hammer, S. E., Suchentrunk, F., Tiedemann, R., Hartl, G. B. \& Feiler, A. (1999). Mitochondrial DNA sequence relationships of the newly described enigmatic Vietnamese bovid, Pseudonovibos spiralis. Naturwissenschaften 86: 279-280.

Hoffmann, R. S. (1986). A new locality for the kouprey from Viet-Nam, and an archeological record from China. Mammalia 50: $391-395$.

IUCN (International Union for the Conservation of Nature and Natural Resources, The World Conservation Union). (1999). Red data book. Mammalia. Gland, Switzerland.

Janis, C. M. \& Scott, K. M. (1987). The interrelationships of higher ruminant families with special emphasis on the members of the Cervoidea. Amer. Mus. Novit. 2893: 1-85.

Lekagul, B. \& McNeeley, J. A. (1977). Mammals of Thailand. Bangkok: Association for the Conservation of Wildlife, Sahakarnbhat Co.

Macdonald, A. A. \& Yang, L. N. (1997). Chinese sources suggest early knowledge of the 'unknown' ungulate (Pseudonovibos spiralis) from Vietnam and Cambodia. J. Zool. (Lond.) 241: 523-526.

Nadler, T. (1997). Was ist Pseudonovibos spiralis? Zool. Garten N.F. 67: 290-292.
Nowak, R. M. (1999). Walker's mammals of the world. Vol. II. 6th edn. Baltimore: The Johns Hopkins University Press.

Peter, W. P. \& Feiler, A. (1994a). Hörner von einer unbekannten Bovidenart aus Vietnam (Mammalia: Ruminantia). Faun. Abh. Staatliches Mus. Tierkd. Dresden 19: 247-253.

Peter, W. P. \& Feiler, A. (1994b). Eine neue Bovidenart aus Vietnam und Cambodia (Mammalia: Ruminantia). Zool. Abh. Staatliches Mus. Tierkd. Dresden 48: 169-176.

Pine, R. H. (1994). New mammals not so seldom. Nature (Lond.) 472: 593.

Ridgway, R. (1912). Color standards and color nomenclature. Washington, D.C.: Privately published by the author, 43 pp. + 53 pls.

Schaller, G. (1998). On the trail of new species. Int. Wildl. 28(4): 36- 43.

Schaller, G. B. (1999). Lost world of the Annamites. Explorers J. 77: 6-7.

Schaller, G. B. \& Rabinowitz, A. (1995). The saola or spindlehorn bovid Pseudoryx nghetinhensis in Laos. Oryx 29: 107-114.

Schaller, G. B. \& Vrba, E. S. (1996). Description of the giant muntjac (Megamuntiacus vuquangensis) in Laos. J. Mammal. 77: 675-683.

Sutton, R. L. \& Sutton, R. L., Jr. (1930). The long trek: around the world with camera and rifle. St. Louis: C. V. Mosby Company.

Thomas, H. (1994). Anatomie crânienne et relations phylogénétiques du nouveau bovidé (Pseudoryx nghetinhensis) déouvert dans la cordillère annamitique au Vietnam. Mammalia 58: 453481.

Timmins, R. J. (1996). Another muntjac materializes: more mammal finds in Laos. BBC Wildlife 14: 22-23.

Timmins, R. J., Evans, T. D., Khounboline, K. \& Sisomphone, C. (1998). Status and conservation of the giant muntjac Megamuntiacus vuquangensis, and notes on other muntjac species in Laos. Oryx 32: 59-67.

Urbain, A. (1937). Le kou prey ou boeuf gris cambodgien. Bull. Soc. Zool. Fr. 62: 305-307.

Wharton, C. H. (1957). An ecological study of the kouprey, Novibos sauveli (Urbain). Manila: Monogr. Inst. Sci. Tech. 5: 1-111.

Wilson, D. E. \& Reeder, D. M. (Eds). (1993). Mammal species of the world: A taxonomic and geographic reference. 2nd edn. Washington, D.C.: Smithsonian Institution Press. 